\title{
The Role of Islamic Work Ethics Integration in Intellectual Capital for SMEs Performance Improvement
}

\author{
Abdul Hakim ${ }^{1}$, Dista Amalia Arifah ${ }^{2}$, Norazamina Mohamed ${ }^{3}$ \\ Dept. of Accounting, Universitas Islam Sultan Agung ${ }^{1}$, Dept. of Accounting, Universitas \\ Islam Sultan Agung \& Economics Doctoral Program, Diponegoro University, Semarang \\ Indonesia $^{2}$ UiTM Malaka, Malaysia $^{3}$ \\ \{abdulhakim@unissula.ac.id ${ }^{1}$,distaamalia@gmail.com² ${ }^{2}$,
}

\begin{abstract}
Companies with a good intellectual capital can be more competitive in the current business era if the companies are well managed. It is also applicable for Small and Medium Enterprises (SMEs). Islamic work ethics integration toward intellectual capital is expected to optimize the company performance further. This study aimed to explore and discuss the effect of Islamic work ethics integration in intellectual capital, which consist of human capital, structural capital, organizational capital, spiritual capital and technological capital, toward SME performance improvement. The populations of this study were SMEs in Semarang. This study used purposive sampling as the sampling technique. Based on the data processing results, it obtained 300 sample data. The results showed that human capital, structural capital, organizational capital, spiritual capital and technological capital have no effect on SMEs performance, thus the hypotheses were rejected. The existing SMEs do not explore intellectual capital as a competitive advantage. As the result, the integration of Islamic work ethics in intellectual capital does not improve the performance.
\end{abstract}

Keywords: Islamic work ethics, intellectual capital, performance, SMEs creative industry.

\section{Introduction}

Along with the science-based economy changes, intellectual capital plays an important role in the progress of a company. Especially for companies engaged in the creative industry. Companies with good intellectual capital can be more competitive in today's business era. It may be argued that intellectual capital is one of the determinants for a company's performance. This also applies to companies at the small and medium enterprises level. Small and medium enterprises (SMEs) have a strategic role in national economic development. It is because, SMEs not only play a role in economic growth and employment, but SMEs also play a role in the distribution of development results (Zuliyati \& Delima, 2017).

A company can work more effectively and efficiently by upholding an ethical framework that monitors and regulates their exertion. Spesifically in term of Islamic ethics with its 
principles. Islamic ethics offers the basics for impartiality and tolerance to the various needs, difficulties and challenges that a company faces (Zin et al., 2017); (Zin \& Adnan, 2016). It is expected that the integration of Islamic work ethics in intellectual capital will further optimize company performance. This is supported by Zin \& Adnan (2016), that intellectual capital and Islamic values are substantially and significantly related to the SMEs performance. Furthermore,(Khalique, Bontis, Shaari, \& Md. Isa, 2015)suggested that from 5 elements of intellectual capital which consist of human capital, structural capital, organizational capital, spiritual capital and technological capital, all proved to have a significant effect on company performance except for the human capital element.

The study examined that the current intellectual capital as a determinant of company's performance is not optimal. This also applies to companies at the small and medium enterprises level. It is expected that the integration of Islamic work ethics in intellectual capital will further optimize company performance.This study aimed to explore and discuss the effect of Islamic work ethics integration in each element of intellectual capital toward SMEs performance improvement. The urgency of this research is with Islamic work ethics integration in intellectual capital, the owners and managers of SMEs can be more effective and efficient in managing intangible assets as represented by intellectual capital. A better intellectual capital management will improve the SMEs performance.

\section{Literature Review}

\subsection{Resourced Based View}

Resourced based view (RBV) discusses the company's internal resources, capabilities and their relationship with strategic decision making. In addition, RBV describes how company resources affect the competitive outcomes and process externally. RBV theory views the company as a pool of resources and capabilities (Wernerfelt, 1984). The assumption of RBV is companies compete based on resources and capabilities. Differences in the company's resources and capabilities with competing companies will give a competitive advantage. Company resources are divided into: tangible, intangible and human resources. The company capability is measured by what the company can do with the resources. The resources referred to all assets, capabilities, organizational process, company characteristics, information, knowledge and so on. These resources are within the control of the company for strategy implementation in order to achieve effectiveness and efficiency (Purnomo, 2011). According to RBV, the strategy is carried out by allocating resources to market needs when the competitor's capabilities are insufficient in orfer to give effective results for the company. Company resources and capabilities are important things in business strategy. Valuable resources can affect the various efforts of the company.

The company performance depends on internal consistency among the three elements of the corporate triangle strategy. The three elements are resources, efforts and organizational mechanisms, including organizational structure, system and process. The successful company growth and sustainability will depend on developing new resources, as well as exploiting old resources (Wernerfelt, 1984). In an organization, RBV is a business management tool to determine the strategic resources to a company. The fundamental principle of RBV is the basis for the company competitive advantage, spesifically in the application of pooling company resources. 
In order to transform a temporary competitive advantage into a sustainable competitive advantage, these resources must be heterogeneous and permanent. The key points of the RBV theory are (Wernerfelt, 1984); (a). Identify the most important (main) potential company resources; (b). Evaluate whether these resources meet the following criteria or not (Valuable, Rare, Inimitable, Not substitutive; (c). Proper maintenance, management and protection of resources that can improve performance.

\subsection{Islamic Work Ethics}

Ethics can be interpreted as norms, moral principles, or values with the goodness contained. The goodness is believed as righteousness by individual, to be used as a guide in behaving and acting in social relations. Ethics in business is a reflection of conscience(Rahardjo, 2018). Ethics according to Islam is defined as a good character (trait). The motivation for Islamic ethics is contained in the doctrine that in every aspect of life a person must always do good and stay away from wickedness (Rahardjo, 2018). Islamic principles consist of laws and ethics which are related to work. A Muslim is required to work and operate his business consistent with the existing principles. Business ethics helps in economic development, besides contributing to organizational success (Zin, Adnan, Hasan, \& Abdullah, 2017).

Organizations can work more effectively and efficiently by upholding an ethical framework that monitors and regulates their deployment. In addition, Islamic ethics offers the basics for impartiality and tolerance of the various needs, difficulties and challenges faced by an organization. Islamic ethics is an ethical as reflected in Qur'an and explained by the Prophet Muhammad through actions and words (in Zin et al., 2017). Islamic ethics consists of four basic qualities: i). Wisdom, ii). Courage, iii). Patience and iv). Justice. Islamic ethics is a form of human spiritual practice, embedded in his soul and demonstrated by his actions. It includes right action against God, family members and society. Islamic ethics will guide people, especially entrepreneurs, in securing right actions and refraining from bad action. In addition, Islamic work ethics shows that life will not be meaningful for someone who does not work, and involvement in business activities is a responsibility.

As intellectual capital supports the competitive advantage of an entity, a good Muslim entrepreneur has intellectual capital related behaviours such as: persistence, commitment, dedication, creativity, cooperation and being able to compete will clearly strengthen the company's value fulfilment (Zin et al., 2017). This is due to the fact that individual development in the Islamic approach does not only accommodate the primary needs of humans, but also provides opportunities for material life which are better applied to organizational success. Therefore, in managing the intellectual capital of a company, entrepreneurs must internalize Islamic ethics such as prayer, patience, gratitude, relying on Allah, confidence, satisfaction, self-calmness, gentleness, simplicity, knowledge, sincerity, loyalty, self-respect. In addition, an entrepreneur who tries to improve business performance as a means of piety to Allah SWT, he actually worships according to the lessons of Prophet Muhaamad Zin et al., (2017).

\subsection{Intellectual Capital}

There are several definitions of intellectual capital. One of the definitions is from Lonnqvist and Mettanen (2002) who defined intellectual capital as a concept. Intellectual capital refers to non-physical or intangible assets or invisible. It is related to human knowledge 
and experience and the technology used. IC has the potential to advance organizations and society (Rupidara, 2008).

In general, intellectual capitalis grouped into 3; Human Capital, Structural Capitaland, Relational Capital. Cerbioni \& Parbonetti (2007) suggested a framework that divides intellectual capital into three groups, which is useful in gathering the data required in intellectul capital disclosure, as follows: (a). Human Capital; reflects the company's collective ability to produce the best solutions based on the knowledge possessed by people in the company. Human capital will improve if the company is able to use the knowledge possessed by its employees such as; intellectual, expertise, creativity and ways of working; (b). Structural Capital; the ability of an organization or company to fulfil the company's routine process and structures. It supports the employees' efforts to produce optimal intellectual performance and overall business performance, for example company operational system, manufacturing process, organizational culture, management philosophy and all forms of intellectual property of a company. An individual can have a high intellectual level. However, if the organization has bad system and procedure, the intellectual capital cannot be optimal; (c). Relational Capital; the harmonious relationship that the company has with its partners. The partners are such as reliable and quality suppliers, loyal customers who are satisfied with the service of the company concerned. The harmonious relationship also can be created by the company's relationship with the government and community, all external relations with consumers such as; suppliers, partners, networks and regulators.

In this study. Intellectual capital is grouped 5 sub-elementsas referred to (Zin et al., 2017); (Zin \& Adnan, 2016) and (Khalique et al., 2015), including: (i). Human Capital; represents the availability of knowledge in an organization. Bontis (1998) defined Human Capital as the company ability to get the best solution from the knowledge of its employees; (ii). Organizational Capital; including all non-human knowledge in the organization, such as databases, process manuals, organizational charts, strategies, routines and anything that has higher value in business more than its physical value (Bontis, 1998); (iii). Relational Capital; refers to the organization's relationships with the outside environment such as alliances, suppliers, customers, partners, competitors and delivery networks (Bontis, 1998); (iv). Spiritual Capital; spiritual capital which contains of religious views and ethical beliefs. Al Ghazali (1983) (Zin et al., (2017))believed that spirituality is what creates beliefs for religion. This is based on passion, strength, influence and knowledge as the results from religion; (v). Technological Capital; intangible capital established in the process of innovation and technical training. Technical knowledge refers to the use of production innovation methods and product technology that results company competitive advantage (Zin et al., (2017)).

\subsection{Small and Medium Enterprises}

SMEs Definition. Some institutions or agencies even provide a definition for Small and Medium Enterprises (SMEs) including the Ministry of Cooperatives and Small and Medium Enterprises (Menegkop and UKM), the central statistics agency (BPS), and Law number 20 of 2008. According to the Ministry of Cooperatives and Small and Medium Enterprises (Menegkop and UKM), the definition of SMEs is as follows: Small business (UK) is a business entity that has a net worth of at most Rp. 200,000,000, excluding land and buildings for business premises, and has annual sales of at most Rp. 1,000,000,000. Meanwhile, Medium Enterprises (UM) is a business entity owned by Indonesian citizens which has a net worth greater than Rp. 200,000,000 up to Rp. IDR 10,000,000,000, excluding land and buildings. 
Central statistics agencydefined SMEsbased on the workforce quanity: Small business is business entities that have a workforce of 5 to 19 people, while medium enterprises are business entities that have a workforce of 20 to 19 people. 99 people. In the perspective of its development, SMEs can be classified into 4 (four) groups: (1). Livelihood Activities are SMEs that are used as job opportunities to earn a living, which are more commonly known as the informal sector, for instance a street vendor; (2). Micro Enterprise is an SME that has the character of a craftsman but is not yet entrepreneurial; (3). Small Dynamic Enterprise is an SME that have an entrepreneurial spirit and are able to accept subcontract and export jobs; (4). Fast Moving Enterprise is an SME that has an entrepreneurial spirit and will transform into a big business (UB).

\subsection{Previous Research}

Kamukama \& Sulait (2017)investigated intellectual capital and competitive advantage of SMEs in Uganda. The independent variables consist of structural capital, human capital and relational capital. Meanwhile the dependent variable is competitive advantage. The results of their research show that the existing independent variables are strong predictors of competitive advantage. Zin \& Adnan (2016)examined on how intellectual capital and Islamic values affect the SMEs performance. The input of this research is intellectual capital and Islamic values are substantially and significantly related to the SMEs performance.

Khalique, Bontis, Shaari, \& Md. Isa (2015)analyzed the relationship between intellectual capital components and company performance of electronic SMEs in Pakistan. The independent variables consist of Intellectual Capital, Structural Capital, Human Capital, Customer Capital, Social Capital, Technology Capital and Spiritual Capital, whereas the dependent variable is organizational performance. The results show that the regression model is fit, only human capital is not significant, in 6 days the 7 the proposed hypotheses are proven significant. Nkundabanyanga, Ntayi, Ahiauzu, \& Sejjaaka (2014)investigated intellectual capital as a mediation between board members and company performance on service companies in Uganda. The independent variables consist of intellectual capital and Board Members, while the dependent variable is Company Performance. The results of their research indicate that intellectual capital cannot mediate the relationship between board members and company performance. Board members have a positive effect on company performance.

$\mathrm{Su}$ (2014)examined the influence of ethics on intellectual capital of IT companies in Taiwan. The independent variable consists of Business Ethics, while the dependent variables are Organizational Capital, Structural Capital and Human Capital. The research data were obtained through a questionnaire from 503 respondents. The results of this research indicate that Business Ethics has a positive effect on IC. Indriastuti \& Arifah (2012)researched the effect of intellectual capital and innovation on the SMEs performance Semarang. The independent variables consist of intellectual capital (Human Capital, Structural Capital and Relational Capital) and Innovation. Meanwhile, the dependent variable is the SMEs performance. The results of their research indicate that Structural Capital and Relational Capital have an effect on SME performance while innovation has no effect on SME performance. 


\subsection{Hypothesis}

The performance of a company depends on internal consistency among the three elements of the corporate triangle strategy. The elements are resources, efforts and organizational mechanisms, including organizational structure, system and process. The successful growth and sustainability of the company will depend on developing new resources, as well as exploiting old resources(Wernerfelt, 1984). In an organization, RBV is a business management tool that uses to determine the strategic resources available to a company. The fundamental principle of RBV is the basis for the competitive advantage in a company, especially in the application of pooling company resources. Intellectual capital is a form of resource that plays an important role in formulating company policies and strategies to compete with its competitors. In the end, intellectual capital plays an important role in the company performance. Besides intellectual capital, a company can work more effectively and efficiently by upholding an ethical framework that monitors and regulates their deployment. Moreover, Islamic ethics with its principles offers the basics for impartiality and tolerance to the various needs, difficulties and challenges that a company faces (Zin et al., 2017); (Zin \& Adnan, 2016).

It is expected that Islamic work ethics integration in intellectual capital will further optimize company performance. This is supported by Zin \& Adnan (2016). Their research resulted several inputs such as; intellectual capital and Islamic values are substantially and significantly related to the SMEs performance. The same result is suggested by(Khalique et al., 2015). from the 5 elements of intellctual capital; Human Capital, Structural Capital, Organizational Capital, Spiritual Capital and Technological Capital, all proved to have a significant effect on company performance except for the element of Human Capital. Based on the existing background, the following hypothesis is proposed:

a) $\mathrm{H}_{1}$ : The integration of Islamic work ethics in Human Capital has a positive effect on SME performance

b) $\mathrm{H}_{2}$ : The integration of Islamic work ethics inStructural Capitalhas a positive effect on SME performance

c) $\mathrm{H}_{3}$ : The integration of Islamic work ethics inOrganizational Capitalhas a positive effect on SME performance

d) $\mathrm{H}_{4}$ : The integration of Islamic work ethics inSpiritual Capital has a positive effect on SME performance

e) $\mathrm{H}_{5}$ : The integration of Islamic work ethics inTechnological Capitalhas a positive effect on SME performance

\subsection{Research Framework}

Nowadays, intellectual capital is considered as the determinant of a company's success. Intellectual capital management will significantly improve the company performance(Khalique et al., 2015). In addition of intellectual capital, a company can work more effectively and efficiently by upholding an ethical framework that monitors and regulates their deployment. Moreover, Islamic ethics with its principles offers the basics for impartiality and tolerance to the various needs, difficulties and challenges that a company faces (inZin et al., 2017); (Zin \& Adnan, 2016). It is expected that the integration of Islamic work ethics in intellectual capital will further optimize company performance. 


\section{Method}

\subsection{Population and Sample}

The populations in this study were the SMEs in the creative industry sector of Semarang. It involved 45,297 businesses (National Economic Census 2016). The creative industries are divided into 3 dominant sub-sectors including culinary (67.66\%), fashion (15\%) and crafts $(14.56 \%)$. The sampling was taken by non-probability (not random) with purposive sampling method based on considerations. Non-probability sample selection means population elements do not have the same chance to be selected as sample. The respodents are managers or owners of SMEs, by considering the following criteria: (a). SMEs creative industry that have been operating for at least three years; (b). SMEs that the products according to sharia

\subsection{Variable Operational Definition}

\section{a) Intellectual Capital}

The framework of intellectual capitalin this study usedthe framework from Zin, Adnan, Hasan, \& Abdullah (2017) and (Khalique et al., 2015). They divided intellectual capital into five elements: (i). Human Capital. Moghadam et.al (2015) (inZin et al., (2017))proposed several Islamic work ethics such as; trust, dedication, commitment, hard work, responsibility and fairness can inspire employees to have a greater human capital and work with their abilities for business development. The questionnaire regarding Human Capital consists of 6 questions filled in to what extent the respondent disagrees or agrees with the existing statements on the Likert scale $(1=$ Strongly Disagree to $5=$ Strongly Agree); (ii). Organizational Capital. Organizational Capital is related to the day-to-day or internal company operational procedures. Organizational capital items that related to Islamic work ethics include; operating a business, organizational work procedures, system, process and philosophy. These must be carried out in accordance with existing Islamic ethics (Islamic Work Ethics) (Zin et al., 2017). The questionnaire regarding organizational capital consists of 6 questions filled in to what extent the respondent does not agree or agree with the existing statements on a Likert scale $(1=$ Strongly Disagree to $5=$ Strongly Agree); (iii). Relational Capital. Relational capital is about the relationship between the company and external parties. Relational capital items refer to alliances, suppliers, customers, competing partners and delivery networks. The questionnaire regarding relational capital consists of 7 questions filled in to what extent the respondent disagrees or agrees with the existing statements on a Likert scale $(1=$ Strongly Disagree to $5=$ Strongly Agree); (iv). Spiritual Capital. Spiritual capital is based on the passion, power of influence and knowledge generated from religion (Berger \& Hefinar, 2003; Liu, 2008 in(Zin et al., 2017)), The questionnaire regarding spiritual capital consists of 4 questions filled in to what extent the respondent does not agree or agree with the existing statements on a Likert scale $(1=$ Strongly Disagree to $5=$ Strongly Agree); (v). Technological Capital. Technological capital is an intangible capital founded on a process of innovation and technical training consisting of research and development (R\&D) and protection rights (Khalique et al., 2015). The questionnaire regarding technological capital consists of 4 questions filled in to what extent the respondent disagrees or agrees with the existing statements on a Likert scale $(1=$ Strongly Disagree to $5=$ Strongly Agree $)$. 


\section{b) Data Collecting Method}

The method used in this research is by distributing questionnaires. The data collected directly to the managers or owners of SMEs creative industry, especially SMEs with products that comply with sharia in Semarang.

\section{c) Validity Test and Reliability Test}

The validity test is used to measure whether a questionnaire is valid or not. A questionnaire is valid if the statements on the questionnaire are able to reveal measurable research. The significance test is carried out by comparing the calculated $r$ value with the $r$ table, for degree of freedom $(\mathrm{df})=\mathrm{n}-2$ with a significance level of $0.05 \mathrm{as}$ the number of samples. If $\mathrm{r}$ count $>\mathrm{r}$ table and is positive, then the variable is valid, whereas if $r$ count $>r$ table, then the variable is invalid (Ghozali, 2016). Reliability test is a tool for measuring a questionnaire which is an indicator of a variable or construct. A questionnaire can be said to be reliable the answer is consistent or stable over time. A construct or variable is said to be reliable if it gives valueCronbach Alpha> 0.6 (Ghozali, 2016).

\section{Result and Discussion}

\subsection{Result}

\section{a) Research Object Description}

The populations in this study were SMEs of creative industries in Semarang year 2019. The sampling used purposive sampling technique. The details of sample acquisition are in table 1. 345 questionnaires were distributed, in the period July - August 2019. 317 questionnaires were filled in and returned, whereas 28 questionnaires were not returned. There were 17 questionnaires that could not be processed because the filling was incomplete and did not meet the existing criteria, so the data that could be processed were 300 copies $(99.87 \%)$.

Table 1. Data acquisition result

\begin{tabular}{lcc}
\hline \multicolumn{1}{c}{ Information } & Total & \% \\
\hline Questionnaires sent & 345 & 100.00 \\
Non-returned questionnaires & -28 & 0.08 \\
Returned questionnaires & 317 & 99.92 \\
Unprocessed questionnaires & -17 & 0.05 \\
Ready to be processed questionnaires & 300 & 99.87 \\
\hline \multicolumn{2}{c}{ Source: Processed primary data, 2019 }
\end{tabular}

\section{b) Description of Respondent}

Based on the data in table 2, it is found that in terms of gender, no one dominates among 300 respondents. There is an almost equal number of male and female entrepreneurs, for 136 $(45 \%)$ and 164 respondents $(55 \%)$. The age range of 21 to 30 years old dominates the SME entrepreneurs; the total is 88 respondents $(29 \%)$. Meanwhile the ages of 41 to 50 years old are 74 respondents $(25 \%)$, ages 31 to 40 years old are 70 respondents $(23 \%)$ and those under 20 years old were 32 respondents $(11 \%)$. The education level of respondents was dominated by 
high school graduates or equivalent as many as 136 respondents $(45 \%)$. The second highest number was followed by respondents with higher education levels of 83 respondents $(28 \%)$, the next sequence was junior high school graduates or equivalent as many as 41 respondents $(14 \%)$ and the rest were elementary school graduates totalling 32 respondents $(11 \%)$ and anonymous 8 respondents (3\%). The SMEs that became respondents were dominated by SMEs with a business age range above 3 years to 10 years as many as 115 respondents $(38 \%)$. New SMEs with business age $<=3$ years with 107 respondents $(36 \%)$ dominating the second largest number. It is followed by SMEs with business ages above 10 years to 20 years as many as 51 respondents $(17 \%)$ and the smallest number was SMEs with age business $>20$ years, 27 respondents $(9 \%)$.

Table 2. Respondent description.

\begin{tabular}{|c|c|c|c|}
\hline No. & Information & Total & $\%$ \\
\hline \multirow[t]{4}{*}{1} & Gender & & \\
\hline & Male & 136 & $45 \%$ \\
\hline & Female & 164 & $55 \%$ \\
\hline & Total & 300 & $100 \%$ \\
\hline \multirow[t]{7}{*}{2} & Entreprenur age & & \\
\hline & $<=20$ years old & 32 & $11 \%$ \\
\hline & 21 yearsold - 30 years old & 88 & $29 \%$ \\
\hline & 31 years old - 40 years old & 70 & $23 \%$ \\
\hline & 41 years old -50 years old & 74 & $25 \%$ \\
\hline & $>50$ years old & 36 & $12 \%$ \\
\hline & Total & 300 & $100 \%$ \\
\hline \multirow[t]{7}{*}{3} & Educational Level & & \\
\hline & Higher Education & 83 & $28 \%$ \\
\hline & Senior High School or equivalent & 136 & $45 \%$ \\
\hline & Junior High School or equivalent & 41 & $14 \%$ \\
\hline & Elementary School orequivalent & 32 & $11 \%$ \\
\hline & No description & 8 & $3 \%$ \\
\hline & Total & 300 & $100 \%$ \\
\hline \multirow[t]{6}{*}{4} & Company age & & \\
\hline & $<=3$ years & 107 & $36 \%$ \\
\hline & $>3$ years -10 years & 115 & $38 \%$ \\
\hline & $>10$ years- 20 years & 51 & $17 \%$ \\
\hline & $>20$ years & 27 & $9 \%$ \\
\hline & Total & 300 & $100 \%$ \\
\hline
\end{tabular}

Source: Processed primary data, 2019

\subsection{Data Analysis}

a) Descriptive Statistic

Table 3. Descriptive statistic result

\begin{tabular}{lcc}
\hline \multicolumn{1}{c}{ Variable } & Mean & Deviation Standard \\
\hline Performance & 17.59 & 3.451 \\
Human Capital & 23.16 & 4.599 \\
Organizational Capital & 21.60 & 4.931 \\
Relational Capital & 25.56 & 6.028 \\
Spiritual Capital & 17.90 & 3.369 \\
Technology Capital & 15.49 & 3.640 \\
\hline
\end{tabular}




\begin{tabular}{lccc}
\hline & Variable & Mean & Deviation Standard \\
\hline $\mathrm{N}$ & 300 & \\
\hline
\end{tabular}

In table 3, the existing descriptive statistics show that the average value of each variable is greater than the standard deviation value. This means that the average value that exists is a reflection of the overall existing data. Meanwhile, the distribution of data for both the dependent and independent variables tends to be normally distributed.

\section{b) Validity and Reliability Test}

Table 4. The result of validity and reliabiliy test

\begin{tabular}{|c|c|c|c|c|c|}
\hline & $\begin{array}{l}\text { Human } \\
\text { Capital }\end{array}$ & $\begin{array}{c}\text { Organizational } \\
\text { Capital }\end{array}$ & $\begin{array}{c}\text { Relational } \\
\text { Capital }\end{array}$ & $\begin{array}{c}\text { Spiritual } \\
\text { Capital }\end{array}$ & $\begin{array}{c}\text { Technology } \\
\text { Capital }\end{array}$ \\
\hline \multicolumn{6}{|c|}{ Validity test on each question item from intellectual capital element } \\
\hline Item 1 & .719 & .673 & .723 & .920 & .885 \\
\hline Item 2 & .764 & .814 & .707 & .945 & .861 \\
\hline Item 3 & .742 & .822 & .850 & .908 & .796 \\
\hline Item 4 & .742 & .866 & .804 & .954 & .862 \\
\hline Item 5 & .861 & .887 & .789 & & \\
\hline Item 6 & .754 & .737 & .859 & & \\
\hline Item 7 & & & .847 & & \\
\hline \multicolumn{6}{|c|}{ Reliability test on each intellectual capital element } \\
\hline Cronbach's Alpha & .857 & .888 & .905 & .949 & .872 \\
\hline $\mathrm{N}$ of Items & 6 & 6 & 7 & 4 & 4 \\
\hline
\end{tabular}

The validity test is used to measure whether a questionnaire is valid or not. A questionnaire is valid if the statements on the questionnaire are able to reveal measurable research. Based on the results of the validity test, it is found that each item on the intellectual capital element has $r$ count $>0.3$, so it can be concluded that the questionnaire item is valid. Reliability test is a tool for measuring a questionnaire which is an indicator of a variable or construct. From the reliability test results, each intellectual capital element has a value $>0.60$, so it can be said that all elements are reliable.

Table 5. The result of Kaiser Meyer Olkin (KMO) test

\begin{tabular}{lll}
\hline Kaiser - Meyer - Olkin Measure of Sampling Adequacy & $\mathbf{. 8 7 8}$ \\
\hline \multirow{3}{*}{ Bartlett's Test of Sphericity } & Approx. Chi-Square & 7096.030 \\
& df. & 496 \\
& Sig. & .000 \\
\hline
\end{tabular}

\section{c) Factor Analysis}

Factor analysis is a technique used to look for factors that can explain the relationship or correlation among the observed various independent indicators. In table 5, the KMO value is 0.878 , which means it is greater than 0.5. Meanwhile, the significance generated from Bartlett's Test of Spherecity is 0.000 . Based on the results, it can be concluded that the variables and samples used can be analyzed further 


\section{d) Classical Assumption Test}

Table 6. The result of Kaiser Meyer Olkin (KMO) test

\begin{tabular}{lcccc}
\hline \multicolumn{1}{c}{ Element } & \multicolumn{2}{c}{ Multicollinearity } & Heterocedasticity & Normality \\
\hline \multicolumn{1}{c}{ Intellectual Capital } & Tolerance & VIF & Sig. & Asymp. Sig. (2-tailed) \\
\hline Human Capital & .598 & 1.671 & .429 & $.057^{\mathrm{c}}$ \\
Organizational Capital & .356 & 2.811 & .788 & \\
Relational Capital & .440 & 2.272 & .965 & N of Data 300 \\
Spiritual Capital & .594 & 1.684 & .376 & \\
Technology Capital & .514 & 1.945 & .827 & \\
\hline
\end{tabular}

The classical assumption test is carried out in order to obtain an accountable regression model that has unbiased results(Ghozali, 2016). The classical assumptions in this study are were Normality Test, Multicollinearity Test and Heteroscedasticity Test. Normality occurs when the results of the Kolmogorov-Smirnov test are more than 0.05. From the existing test results, it can be concluded that the data is normally distributed with a sig level of 0.057 . In addition, the VIF value results also show that none of the independent variables has a VIF value of more than 10 . Thus there is no multicollinearity between the independent variables in this data processing. Heteroscedasticity occurs if the Glejser test results have tk sig $<0.5$. Based on the existing test results, all existing variables have tk sig $>0.5$, therefore the equation model is free from heteroscedasticity.

\section{e) Hypothesis Test}

Table 7. The result of hypothesis test

\begin{tabular}{lccc}
\hline \multicolumn{1}{c}{ Element } & \multicolumn{3}{c}{ Hypothesis Test } \\
\hline \multicolumn{1}{c}{ Intellectual Capital } & t-test & f-test & Det Coeff \\
\hline Human Capital & 0.429 & & \\
Organizational Capital & 0.788 & & \\
Relational Capital & 0.965 & 0.587 & 0.013 \\
Spiritual Capital & 0.376 & & \\
Technology Capital & 0.827 & & \\
\hline
\end{tabular}

The $t$ statistical test basically shows how far the influence of one independent variable in explaining the variation of dependent variable. The results of the existing tests show that the $t$ test of each intellectual capital element has a significance value of $>0.05$. Thus there is no effect of the independent variable on the dependent variable or in other words the hypothesis is rejected. In order to test the role significance of Islamic Work Ethics interaction in Intellectual Capital on the SMEs performance, it used the F test. The test results have a significance value of $0.587>0.05$. This means that the role of Islamic work ethics in Intellectual Capital simultaneously does not affect the performance of SMEs.

The determination coefficient is intended to measure the ability of the model to explain the dependent variation. The determination coefficient is between zero and one. The small value of R2 means that the ability of the independent variables to explain the dependent variable is very limited. A value close to one is needed to predict the dependent variable(Ghozali, 2016). The existing test results show that the determination coefficient is only $0.013(1.3 \%)$. Therefore, the role ability of Islamic work ethics in the Intellectual Capital element has very limited abilities in explaining the SMEs performance. 


\subsection{Discussion}

Based on the number of questionnaires distributed, in general, the questionnaire has a large response rate, which is close to $100 \%$. In addition, the questionnaire also fulfils the validity and reliability test. This means that the questionnaire meets valid and reliable requirements. The analysis results indicate that the data has passed the classical assumption test. On the other hand, the results of the analysis did not pass the hypothesis test, thus all hypotheses were rejected. The rejection of this hypothesis is supported by a low determination coefficient. The existence of a rejected hypothesis can be seen from the demographics of the respondents. The demographics show that most entrepreneurs have an age range between 21 years old and 30 years old, have high school education or equivalent with a relatively new age of business, under 10 years. Respondents with existing conditions are a reflection of SMEs in general. Narrow job opportunities and lack of competence (dominated by high school respondents or equivalent) made respondents decide to become entrepreneurs. Being an SME entrepreneur is not because of a passion for entrepreneurship, but rather because of an economic need. In other words, the existing SMEs are still trial and error.

The number of women entrepreneurs is slightly more dominant. It is because entrepreneurs in the respondent age range are generally the right age to start a family. As a new family, new needs that cannot be properly fulfilled, so these women try to work as a way to help the family economy. On the one hand, they also cannot leave the family (children), so entrepreneurship is an option that feels right. Most of the business types that become the focus of SMEs are those that are currently trending in the community, for instance various kinds of food, mobile credit, muslim clothing. Existing SMEs are still unable to move from their comfort zone. The type of business chosen is one that still follows market trends, to minimize losses. These entrepreneurs have not been able to develop products that are more creative and try to be different, such as developing new crafts or culinary types. The main focus of existing SMEs is to seek maximum profit by making or selling products that are sure to sell (following market trends), so that the creative side is less developed. Another impact is that when market trends change, it is possible for these SMEs to change types of businesses, according to existing market trends.

The performance of existing SMEs is almost evenly distributed in all businesses. Even if there are those that grow rapidly, the number is not significant and it belongs to SME that focuses on the products creativity selling value. The large number of SMEs with similar types of businesses only follows market trends. As the result, the SME intellectual capital is less developed. Therefore, even though it is integrated with Islamic work ethics which in fact aims to improve performance, it is still not achieved.

\section{Conclusion and Suggestion}

The development of the times, followed by changing trends in business, also results changes in SMEs. Intellectual Capital plays an important role for the progress of a company. It is especially for companies engaged in the creative industry. Companies with good intellectual capital and well managed can be more competitive in today's business era. It can be concluded that intellectual capital is one of the determinants in company's performance. This also applies to small and medium enterprises level. It is expected that the integration of Islamic work ethics in intellectual capital will further optimize company performance. 
The analysis of existing data shows the opposite result, that the integration of Islamic work ethics in intellectual capital has no effect on improving performance. This is because the backgrounds of each entrepreneur, which are the narrow job opportunities and lack of competencies, make entrepreneurship as the right way out. Entrepreneurship is not a passion, so the products only follow market trends. As a result, the product is underdeveloped and the performance achieved is only an average. The product creativity through the optimization of intellectual capital has not been well developed, thus the integration of Islamic work ethics in intellectual capital has no effect on performance improvement.

Suggestions for future research, the respondents can be focused on: (a). Creative SMEs participating in national and international exhibitions; (b). Creative SMEs that already have product showrooms (workshops); (c). Creative SMEs that have websites and regularly issue new product catalogue. SMEs with the aforementioned conditions are considered to maximize the use of intellectual capital in their products. So that the effect of Islamic work ethics integration in intellectual capital on improving the SMEs performance is expected to get better results.

\section{References}

[1] Bontis, N. (1998). Intellectual capital: an exploratory study that develops measures and models. Management Decision, 36(2), 63-76. https://doi.org/10.1108/00251749810204142

[2] Cerbioni, F., \& Parbonetti, A. (2007). Exploring the Effects of Corporate Governance on Intellectual Capital Disclosure: An Analysis of European Biotechnology Companies Keywords: Corporate governance, voluntary disclosure , intellectual capital , board characteristics , European companies ,. European Accounting Review, 16(4), 791-826.

[3] Fanani, Z. (2009). Kualitas Pelaporan Keuangan : Berbagai Faktor Penentu dan Konsekuensi Ekonomis. Jurnal Akuntansi Dan Keuangan, 6(1).

[4] Ghozali, I. (2016). Aplikasi Analisis Multivariate dengan Program IBM SPSS 23.

[5] Ghozali, I., \& Ratmono, D. (2017). Analisis Multivariate den Ekonometrika Teori, Konsep, dan Aplikasi dengan EVIEWS 10 (2nd ed.). Semarang: Badan Penerbit Universitas Diponegoro.

[6] Indriastuti, M., \& Arifah, D. A. (2012). Peningkatan Kinerja Ukm dengan Pengelolaan Intellectual Capital dan Inovasi. In Conference in Business, Accounting and Management (CBAM) (pp. 649-661).

[7] Kamukama, N., \& Sulait, T. (2017). Intellectual capital and competitive advantage in Uganda's microfinance industry. African Journal of Business Management, 8(4), 498-515. https://doi.org/10.1108/AJEMS-02-2017-0021

[8] Khalique, M., Bontis, N., Shaari, J. A. N. bin, \& Md. Isa, A. Ha. (2015). Intellectual capital in small and medium enterprises in Pakistan. Journal of Intellectual Capital, 16(1), 224-238. https://doi.org/10.1108/JIC-01-2014-0014

[9] Nkundabanyanga, S. K., Ntayi, J. M., Ahiauzu, A., \& Sejjaaka, S. K. (2014). Intellectual capital in Ugandan service firms as mediator of board governance and firm performance. African Journal of Economic and Management Studies, 5(3), 300-340. https://doi.org/10.1108/AJEMS-06-2012-0041

[10] Purnomo, R. (2011). Resource-Based View dan Keunggulan Bersaing Berkelanjutan : Sebuah Telaah Kritis Terhadap Pemikiran Jay Barney ( 1991 ). In Proceeding Seminar 
Nasional \& Call For Papers (SCA-1) (pp. 1-16). Purwokerto. Retrieved from jp.feb.unsoed.ac.id

[11] Rahardjo, S. S. (2018). Etika dalam Bisnis \& Profesi Akuntan \& Tata Kelola Perusahaan. Jakarta: Salemba Empat.

[12] Rupidara, N. (2008). Modal Intelektual dan Strategi Pengembangan Organisasi dan Sumber Daya Manusia, (November), 0-27.

[13] Su, H. (2014). Business Ethics and the Development of Intellectual Capital. Journal of Business Ethics, 119(700), 87-98. https://doi.org/10.1007/s10551-013-1623-4

[14] Wernerfelt, B. (1984). A Resource-based View of the Firm. Strategic Management Journal, 5(2), 171-180.

[15] Zin, S. M., \& Adnan, A. A. (2016). How do Intellectual Capital and Islamic Values Relate to Small Business Performance? A Conceptual Framework. Journal of Applied Environmental and Biological Sciences, 6(May), 42-49.

[16] Zin, S. M., Adnan, A. A., Hasan, I., \& Abdullah, T. (2017). Intellectual Capital : How Do Islamic Ethics Rejuvenate It? Asian Social Science, 13(3), 70-79. https://doi.org/10.5539/ass.v13n3p70

[17] Zuliyati, Z., \& Delima, Z. M. (2017). Intellectual capital dan kinerja umkm. In Seminar Nasional dan Call for Paper 2017 Strategi Pengembangan Sumber Daya Manusia melalui Publikasi Jurnal Ilmiah dalam Menyikapi Permenristekdikti No.20 tahun 2017 (pp. 280-290). 